\title{
Civil Rights of State-Owned Enterprises in Managing Rights to State Land
}

\author{
Ayu Trisna Dewi ${ }^{1}$, Tan Kamello ${ }^{2}$, Muhamamad Yamin Lubis ${ }^{3}$, Edi Ikhsan ${ }^{4}$ \\ \{ayutrisnadewi@dharmawangsa.ac.id ${ }^{1}$, tankamello@usu.ac.id², yaminlubis16@gmail.com ${ }^{3}$, \\ edi1@usu.ac.id $\left.{ }^{4}\right\}$ \\ Universitas Sumatera Utara, Indonesia ${ }^{1,2,3,4}$
}

\begin{abstract}
State-Owned Enterprise (SOE) is a public legal entity whose majority of shares belong to state assets. SOE is a business entity generally subject to Law Number 40 of 2007 concerning Limited Liability Company, acting as a civil subject in the private law domain. In the management of state land by SOEs, there are multiple interpretations concerning the definition of state land and its management concept. The problem in this research is related to regulating the civil rights of SOEs in managing state land. This is a descriptive study using a normative legal approach and qualitative data analysis. The problem discussed was the civil rights of SOEs in managing state land due to their authority in managing state land. This research describes how to regulate the SOEs' civil rights in managing state land descriptively using a normative legal approach and qualitative data analysis. The problem discussed was the civil rights of SOEs in managing state land due to their authority in managing state land. The results indicate that SOEs have differences in civil rights arrangements compared to other private legal entities because of the public nature attached to SOEs and their submission to Law on Limited Liability Company. In the practice of SOEs, the characteristics of a public company are more apparent than the characteristics of a private company. Due to their form of ownership, the civil rights of SOEs are the same as other private legal entities. There is a disharmony of regulations related to the position of civil rights of SOEs in the management of state land. To avoid such disharmony, there needs to be a formulation of a new and consistent legal arrangement established by the Indonesian Government.
\end{abstract}

Keywords: Civil, SOEs, Management, State Land

\section{Introduction}

State-Owned Enterprise (SOE) is a business entity whose majority of shares and management belong to state assets. SOEs are representatives of the State related to land, water, space, and natural resources contained there. Those assets are controlled directly or indirectly by the state for the welfare of all Indonesian people. Thus, SOEs can be said as legal business entities with the characteristics of public companies as regulated in Law Number 19 of 2003 concerning State-Owned Enterprises. SOE is one of the drivers of the Indonesian economy, which is expected to encourage efforts to improve the welfare of the Indonesian people. In carrying out its duties and functions, SOE carries out production functions and carries out procuring functions (goods and services procurement). SOEs also have an essential role in their direct involvement in allocating economic resources for the community. 
Establishing SOEs in Indonesia cannot be separated from the mandate of Article 33 of the 1945 Constitution, a constitutional foundation for their existence. Even though it is not directly written or explained in the 1945 Constitution, Article 33 of the 1945 Constitution states that the Indonesian economy is organized based on the principles of a family system. The State should control all critical sectors for the country and affect the people's livelihoods. The earth (land), the water, and all of the natural resources therein are controlled directly or indirectly by the state for the greatest welfare of the people. The use of the term "control directly and or indirectly" illustrates the implementation of state sovereignty. However, the concept of implementing state sovereignty according to the intention and aim of Article 33 of the 1945 Constitution is the sovereignty viewed from internal and external perspectives. When viewed from the meaning of the term "earth" in Article 33 of the 1945 Constitution, it refers to land. There are still multiple interpretations regarding the land's actual ownership and owner authority and who has the right to transfer the rights to the land and or manage the land. Such multiple interpretations arise because Article 33 of the 1945 Constitution mentions that the land is "State Property". Nevertheless, based on the perspective of Land Law, the use of the term "State Property" is not correct because a legal relationship of land is not a relationship based on ownership rights, but the rights to control over the state land by the state. According to Sembiring, the categorization of land as "State Property" should be replaced by "Government Property". This misperception stems from the inability to distinguish between "state" and "government" because, according to him, the government is the one that can have ownership rights over land, not the state [1].

The arrangement and management of SOEs can no longer be carried out with practices that can lead to inefficiency. As a comparison, SOEs or companies in developed countries are characterized by transparency, accountability, and good corporate governance. They become the essential aspects that modern and global corporate businesses must fulfill. The development of business cooperation of SOEs or companies among countries depends on financial gain and the principles of good corporate governance. There needs to be some clarity regarding SOEs'the private or public characteristics of SOEs by adapting the functions and objectives of privatization applicable in limited liability companies. The need for such clarity viewed from the philosophy of SOEs is an interesting phenomenon to study [2]. In carrying out their business activities, as the business entities established by the state under the provisions of Article 9 of the Law on SOEs, SOEs are divided into two forms are SOEs in the form of a Public Company and SOEs in the form of a Persero (Limited Liability Company) [3].

SOE is in the form of Persero belonging to a civil law subject concerning legal entities subject to the Limited Liability Company Law and the Civil Code as the source of material law. The status of a legal entity as a legal subject is authorized to take legal action, such as establishing agreements with other parties and conducting sale and purchase activities that are carried out by its management or legal personality. The term legal personality is now always defined in the sense of a unit separate from its members so that it has gained legal capacity and litigation capacity. Therefore, to be a legal person means to be the subject of rights and duties capable of owning real property, entering into contracts, and suing and being such in its name, separate and distinct from its shareholders [4].

Disharmony of legal arrangements occurs because the regulation of the SOEs Law is juxtaposed with the provisions of the State Finance Law. The State Finance Law categorizes the assets of state-owned companies as part of state finances. This provision seems to provide legitimacy for the state to have the right to intervene in the management of Persero-based SOEs, which are independent legal entities. This is what ultimately leads to changes that impact both the normative and practical order of SOEs management. The state's continuous interference in the management of Persero-based SOEs leads to various problems and sometimes even raises 
the perception of an indication of monopoly. Meanwhile, the SOE Law has explicitly confirmed the validity of all the provisions and principles of limited liability companies in the management of Persero-based SOEs as stipulated in the Limited Liability Company Law [5]. Such a regulation confirms that all principles of independence of Limited Liability Company shall apply to Persero-based SOEs.

Table 1. Number of SOEs by Type 2015-2019

\begin{tabular}{lccccc}
\hline \multicolumn{1}{c}{ Type } & $\mathbf{2 0 1 5}$ & $\mathbf{2 0 1 6}$ & $\mathbf{2 0 1 7}$ & $\mathbf{2 0 1 8}$ & $\mathbf{2 0 1 9}$ \\
\hline Perum (Public Company) & 14 & 14 & 14 & 14 & 14 \\
Persero Tbk (Limited Company) & 20 & 20 & 17 & 16 & 16 \\
Persero (Liability Company) & 84 & 84 & 84 & 84 & 83 \\
\hline Total & 118 & 118 & 115 & 114 & 113 \\
\hline
\end{tabular}

Source: Databoks-katadata [6].

During the last five years, the number of limited liabilities SOEs type decreases. The problem that can be identified from the rationale elaborated above is functional disharmony between the privatization functions of Persero-based SOE and the social functions that SOEs must carry out under the mandate of the elucidation of Article 33 of the 1945 Constitution regarding the management of state land, either directly or indirectly controlled by the state. This has triggered debates among groups who state that the objectives and roles of SOEs must be clearly defined. However, on the one hand, profitability and social functions are the two characteristics of SOEs that distinguish them from cooperatives or private businesses. Thus, the problem of this study is formulated into the question "How is the position of civil rights of SOEs in managing state land based on the prevailing laws and regulations?".

\section{Research Method}

This is descriptive research using a normative legal approach. The data were analyzed using qualitative data analysis by elaborating the regulations regarding the position of SOEs as a civil law subject. Most of the data sources were secondary data, for example, is in related regulations from laws, books, and national and international journals.

\section{Results and Discussion}

\subsection{Regulation about SOEs in Indonesia}

State-Owned Enterprises as separate legal entities in the form of a Limited Liability Company, the main characteristic of SOEs as separate limited liability companies is a clear separation between the management of state land and state assets. Besides, the common law system also explains a separation of power between the Limited Liability Company and its owners (a significant characteristic of the corporation is the distinction between the business and its owners). Black's Law Dictionary states that an entity, other than a natural person, who has sufficient existence in legal contemplation that can function legally, be sued or sue and make decisions through agents as in the case of a corporation [7]. In current practice, the assets separated from a legal entity are regulated in the Law on Limited Liability Companies. 
However, for SOEs as Legal Entities, separating state assets that should refer to the aforementioned legal provision has different perceptions to date. Such different perceptions are motivated by the fact that different laws and regulations that govern the assets of a legal entity have their respective versions. Besides, due to the absence of a comprehensive and consistent legal foundation regulating such a problem, separate assets of the legal subject of Persero-based SOEs continue to invite different opinions and debates [5].

A separate legal entity status owned by SOEs, which has received recognition in Law Number 19 of 2003, has enforced all principles of independence of Limited Liability Company into SOEs institutions, especially for Persero-based SOEs. However, disharmony related to the provisions concerning state-owned enterprise (SOE) institutions in the statutory regulations has resulted in a confusion of law at the normative level [5]. The disharmony occurs in the normative arrangement between Law Number 19 of 2003 concerning SOEs (SOEs Law) and Law Number 17 of 2003 concerning State Finance (State Finance Law) and Law Number 40 of 2007 concerning Limited Liability Company (Limited Liability Company Law). Furthermore, Article 11 states that all provisions and principles that apply to Limited Liability Company are also applicable to Persero as stipulated in Law Number 40 of 2007 concerning Limited Liability Company. Besides being a subject of civil law, i.e., legal entities, Persero-based SOEs are also subject to the general principles in the law of contract and or agreement regulated in the Civil Code when conducting a cooperative relationship or an agreement with other parties or legal subjects. Such collaborative work should not conflict with Article 1313 in conjunction with Article 1338 in conjunction with Article 1320 of the Civil Code in all legal actions in state land management [8].

The Civil Code explains that every subject of civil law, both legal entities and individuals, has the same rights and obligations in a legal relationship, whether originated from a contract sourced from the Law or a contract sourced from the Agreement. In arranging an agreement or a contract, the consensus from the parties involved in the agreement is the most crucial point during the pro codification period. This principle is called the principle of freedom of contract. Article 1108 of the Civil Code states that binding power is a legal consequence of the consensus produced in the agreement [9].

Public legal entities and private legal entities should have the same and equal position as civil law subjects. However, there are still differences in regulations in practice when SOEs take legal actions regarding civil rights in managing state land and or related to other production sectors that concern many people's lives. It seems that public legal entities have broader authority than private legal entities because they can make decisions or regulations that bind other people who are not members of public legal entities. Thus, public legal entities have a more dominant position than other civil legal entities even though both are the same civil law subjects. The domination takes place because the state-owned enterprise is a legal entity with a sovereign body as the state's representatives in managing the rights to state land and other natural resources by following Article 33 of the 1945 Constitution.

Furthermore, disharmony of legal arrangements also occurs because the regulation of the SOEs Law is juxtaposed with the provisions of the State Finance Law. The State Finance Law categorizes "state company assets as part of state finances". This provision seems to provide legitimacy for the state to have the right to intervene in the management of Persero-based SOEs, which are separate legal entities. This is what ultimately leads to changes that impact both the normative and practical order of SOEs management. The state's continuous interference in the management of Persero-based SOEs leads to various problems and sometimes even raises the perception of an indication of monopoly. Meanwhile, the SOEs Law has explicitly confirmed the validity of all the provisions and principles of limited liability companies in managing 
Persero-based SOEs as stipulated in the Limited Liability Company Law. Such a regulation confirms that all principles of independence of Limited Liability Company shall apply to Persero-based SOEs [5].

The management of state land by SOEs can be described by regulating the state's rights to control land as stated in Article 33 of the 1945 Constitution and Basic Agrarian Law which are delegated as the rights to manage the state land by SOEs. The Basic Agrarian Law does not explicitly provide a firm and precise definition of Management Rights. It only mentions the term "management" in the General Elucidation of Number 2 of Part II of the Basic Agrarian Law, i.e., granting rights to land by the State to an individual or legal entity under a particular right on the land-based on its function and purpose, including the right of Ownership, Right to Cultivate, Right of Use of Structures, and Right of Use. Those rights can be interpreted as a concrete form of management rights over the state land given to a ruling body (Department, Service, or Autonomous Region) to be used in implementing their respective duties [10].

\subsection{Managing Right to State Land by SOEs}

At the first time, the term "state land" was introduced by the Dutch colonial government as staats lands domein as contained in Article 519 of Burgerlijk Welboek (BW) and Agrarisch Wet (staatsblad 1870-55) along with its all implementing regulations, including Agrarisch Besluit (staatsblad 1870-118), Koninklijk Besluit (staatsblad 1875-199a), and Zelfsbestuurs Regelen (staatsblad 1872-117). However, since the issuance of Basic Agrarian Law, state land has not been regulated in the Basic Agrarian Law. The regulation of land controlled by the state is regulated in Article 1 and Article 2 of the Basic Agrarian Law, which explains that land controlled by the state is an elaboration of the state's rights to control over land, water, and airspace. Nevertheless, many legal products still use the misconception of state land. State land is often associated with the land that belongs to the state, but it does not. Such understanding is derived from the literal translation of the domain of the state, and it is no longer appropriate to use. It is suggested to use the term "the land controlled by the state" as regulated by the Basic Agrarian Law.

State land is not the land "owned" by the state, reflecting as if there is a private legal relationship between the state and the land controlled by the state. The legal relationship between the state and the land controlled by the state is a public legal relationship. Therefore, the meaning of "directly and indirectly control over the state's land" can be interpreted as management rights.

The first use of the term "Management Rights" is regulated in Regulation of the Minister of Agrarian Affairs Number 9 of 1965 concerning Converting Tenure Rights to State Land and Provisions of Further Policies. Article 2 of the Regulation of the Minister of Agrarian Affairs states that the meaning of state land is the land controlled directly or indirectly by the state. Moreover, for the State agencies' interests, the rights to use the land are also granted to a third party. Therefore, the rights to control as mentioned above are converted into management rights as intended by Article 5 and Article 6 . The management rights over the land last as long as the land is used to benefit the state institutions. Moreover, the meaning of institutions as stipulated in Article 1 of Regulation of the Minister of Agrarian Affairs includes Departments, Directorates, and Autonomous Regions. Then it is also added in Article 7 that "other agencies that require control of state lands to carry out their duties" can also be granted Management Rights. Furthermore, it is also explained that there is a separation between SOEs' capitals derived from state assets and those derived from Non-State Budgets, which are used as the additional capitals in establishing SOEs. The wealth obtained from the profits of state land 
management by SOEs and private entities is not included as the state assets. However, the development and the management of the profits are based on sound corporate principles as regulated in the privatization of corporate legal arrangements and the related regulations. Just like a business entity that runs its business to make profits, SOEs can act like other private businesses entities, profit-oriented [11].

However, in reality, public legal entities have broader authority than civil legal entities because they can make decisions or regulations that bind other people who are not members of public legal entities. Therefore, public legal entities have domination through their stronger position than other civil legal entities even though both are the same civil law subjects. The domination takes place because SOEs are legal entities that have a sovereign body as the state's representatives in managing the rights to state land and other natural resources by following the intent of Article 33 of the 1945 Constitution.

\section{Conclusion}

SOEs are public legal entities that also have the characteristics of private legal entities. Therefore, SOEs are also subject to the principles of civil law and limited liability company law. This is because the capital owned by SOEs with the status of limited liability companies (Persero-based SOEs) is not a state asset. The ratification of Persero-based SOEs is legalized by the Minister of Law and Human Rights. There are two objectives in managing state land by SOEs: social objective and economic objective (profit). However, in practice, there are different views on the position of civil rights between SOEs and other private legal entities because SOEs are public legal entities with private legal entity characteristics after having been privatized since the New Order era.

\section{References}

[1] H. I. Prasetya, "Pengelolaan tanah negara oleh pihak ketiga ditinjau dari perspektif hukum pertanahan dan perbendaharaan negara," SIMPOSIUM Nas. Keuang. NEGARA, no. 3, pp. 628 647, 2018.

[2] E. Rajagukguk, Badan Usaha Milik Negara (BUMN) dalam bentuk perseroan terbatas. Jakarta: Fakultas Hukum Universitas Indonesia, 2016.

[3] I. Ikhwansyah, "Gugatan Terhadap Badan Usaha Milik Negara (BUMN) sebagai PT. Persero daam Perkara Perdata," ADHAPER, vol. 2, 2016.

[4] D. Zimmer, "Legal Personality," in Voc 1602-2002: 400 Years of Company Law, E. GepkenJager, G. van Solinge, and L. Timmerman, Eds. Alphen aan den Rijn, the Netherlands: Kluwer Law International, 2005.

[5] I. Rahadiyan, "Kedudukan BUMN Persero sebagai separate legal entity dalam kaitannya dengan pemisahan keuangan negara pada permodalan BUMN," J. Huk. IUS QUIA IUSTUM, vol. 20, no. 4, pp. 624-640, 2014, doi: 10.20885/iustum.vol20.iss4.art7.

[6] https://databoks.katadata.co.id/datapublish/2020/12/08/berapa-jumlah-bumn-selama-limatahun-terakhir.

[7] H. C. Black, "Black's law dictionary with pronunciations," West Publishing Co. West Publishing Co, St. Paul, Minnesota, 1979.

[8] Abdul Rasyid Saliman, Hukum Bisnis Untuk Perusahaan: Teori Dan Contoh Kasus. Jakarta: Kencana, 2005.

[9] peter de cruz, Perbandingan Sistem Hukum Common law, Civil Law and Socialist Law, CETAKAN V. Jakarta: Nusa Median, Diadit Media, 2016. 
[10] U. Santoso, "Eksistensi Hak Pengelolaan Dalam Hukum Tanah Nasional," Mimb. Huk., vol. 24, no. 2, pp. 275-288, 2012, doi: 10.22146/jmh.16130.

[11] J. P. Saragih, "Milik Negara Politics and Economics of Privatization in The State-Owned Enterprise," J. Ekon. dan Pembang., vol. 22, no. 1, pp. 83-105, 2013. 